\title{
Pengaruh Substitusi Isolat Dan Konsentrat Protein Kedelai Terhadap Sifat Kimia Dan Sensoris Sosis Daging Ayam
}

\section{Effect Of Substituting Isolate Soy Protein (ISP) And Soy Protein Concentrate (SPC) To Chemical And Sensory Profile Chicken Sausage}

\author{
Wea Aanisah Mentari Putri, Fidela Devina Agrippina \\ Jurusan Teknologi Pangan dan Hasil Pertanian, Fakultas Teknologi Pertanian, Universitas Gadjah Mada \\ Bulaksumur, Caturtunggal, Depok, Sleman, Yogyakarta 55281 \\ Email korespondensi: fidela.devina.agrippina@gmail.com
}

\begin{abstract}
Abstrak
Substitusi sosis menggunakan isolat protein dari kacang-kacangan dapat mengurangi biaya produksi dan dapat menghasilkan sosis dengan mutu yang sama. Tujuan dari penelitian ini adalah untuk menentukan sifat kimia dan sifat sensoris dari sosis ayam yang disubstitusi dengan isolat protein kedelai (ISP) dan konsentrat protein kedelai (SPC). Lima buah sampel dipersiapkan: C, sebagai kontrol; ISP 10\%; ISP 20\%; SPC 10\%; dan SPC 20\%. Hasil penelitian menunjukkan bahwa substitusi daging ayam dengan ISP dan SPC akan mempengaruhi sifat kimia sosis ayam. Substitusi akan meningkatkan kadar protein. Sebaliknya, substitusi akan menurunkan kadar air, dan kadar lemak. Tetapi, substitusi tidak berpengaruh secara signifikan terhadap kadar abu $(\mathrm{p}>0,05)$. Berdasarkan sifat sensoris, panelis lebih menyukai sosis yang disubstitusi dengan SPC sebanyak $10 \%$.
\end{abstract}

Kata kunci: Isolat protein kedelai, Konsentrat protein kedelai, Sosis ayam, Sifat kimia, Sifat sensoris.

Abstract

Sausage substitution using protein isolate from nuts can decrease production cost and produce sausage with the same quality. The objective of this study was to determine chemical properties and sensory properties of chicken sausages substituted with ISP and SPC. Five samples were prepared: C, control (without substitution); 10\% ISP; 20\% ISP; 10\% SPC; and 20\% SPC. The result showed that substituting chicken meat with ISP and SPC will influence chemical properties of chicken sausages. It will increase protein content. On the other hand, it will decrease water content, and fat content. But, it doesn't significantly affected to ash content $(\mathrm{p}>0.05)$. Based on the sensory properties, the panelist most likely like the sausage substituted with $10 \%$ SPC.

Keywords: Isolate soy protein, Soy protein concentrate, Chicken sausages, Chemical properties, Sensory properties.

\section{Pendahuluan}

Sosis merupakan salah satu produk olahan daging yang banyak diproduksi. Produksi daging olahan di Indonesia pada tahun 2015 menurut Kementerian Pertanian adalah 296.000 ton (Hartono, 2015). Definisi dari sosis sendiri adalah jenis bahan pangan yang berasal dari potonganpotongan kecil daging yang digiling dan diberi bumbu, dapat langsung disiapkan, dan segera dimasak untuk dimakan. Sosis umumnya terdapat di dalam selongsong. Sosis juga merupakan emulsi minyak dalam air (oil in water atau o/w). Emulsi adalah suatu dispersi atau suspensi cairan dalam cairan lain, yang molekulmolekul kedua cairan itu tidak berbaur tetapi saling berlawanan (Winarno, 2002).

Sosis dapat diolah dari daging sapi, ayam, babi, ikan, dan lainnya. Diantara berbagai daging, daging ayam merupakan pilihan yang banyak dipilih karena ketersediaannya mudah diperoleh. Berdasarkan informasi dari Direktorat Jenderal Peternakan dan Kesehatan Hewan (2016), produksi daging ayam di Indonesia pada tahun 
2016 sebesar 1.689 .584 ton, lebih besar dari daging sapi yang sebesar 524.109 ton dan daging babi yang sebesar 342.346 ton.

Substitusi sosis dengan menggunakan isolat protein dari kacang-kacangan saat ini telah banyak dikembangkan khususnya oleh industri pangan terutama industri pengolahan daging yang menggunakan isolat protein sebagai bahan aditif untuk mensubstitusi daging sehingga penggunaan daging sebagai bahan mentah dapat dikurangi. Hal tersebut dapat mengurangi biaya produksi dan akhirnya dapat menghasilkan sosis dengan mutu yang sama tetapi harganya lebih terjangkau. Selain itu, konsumen vegetarian yang ingin mengonsumsi produk olahan sosis non daging mulai meningkat. Oleh karena itu, substitusi protein hewani dengan protein nabati pada sosis sudah mulai dikembangkan untuk memenuhi pangsa pasar konsumen vegetarian.

Salah satu jenis bahan tambahan yang dapat digunakan dalam substitusi daging dalam sosis adalah isolate soy protein (ISP). ISP banyak digunakan sebagai bahan pengikat pada produk pangan karena sifat fungsional yang dimilikinya. ISP memiliki daya ikat air dan lemak yang baik. Selain itu, ISP juga memiliki kemampuan yang baik dalam membentuk gel (Berghout, Boom \& Goot, 2015 dalam Z.-L. Kang et al., 2016).

Selain ISP, soy protein concentrate (SPC) juga dapat digunakan sebagai bahan aditif untuk mensubstitusi daging. SPC dengan kandungan protein yang cukup tinggi sekitar 70\% (Aberle et al., 2001 dalam Sofiana, 2012) diharapkan dapat memberikan fungsi kulinaris yang memuaskan meskipun harganya yang lebih murah.

Sifat yang dimiliki ISP maupun SPC dapat dimanfaatkan dalam pembuatan sosis ayam. Namun, perlu diketahui bagaimana pengaruh substitusi ISP maupun SPC terhadap sifat kimia serta sensoris sosis ayam agar tetap dapat diterima oleh masyarakat dan memiliki parameter mutu yang baik.

\section{Bahan Dan Metode}

\section{A. Alat dan Bahan}

Bahan yang dibutuhkan adalah daging ayam giling yang diperoleh dari Superindo, tepung ISP dan tepung SPC, tepung tapioka, garam, gula, air es, bawang putih bubuk, lada putih bubuk, minyak nabati, Sodium Tri Poly Phospate (STPP), dan selongsong. Bahan kimia untuk analisis meliputi katalisator, $\mathrm{H}_{2} \mathrm{SO}_{4}$ pekat, aquades, $\mathrm{NaOH}-\mathrm{Na}_{2} \mathrm{SO}_{4}, \mathrm{HCl}$ pekat, indikator bromkresol hijau-metil merah (BCG-MR), Petroleum Eter, asam borat 3\%, timbel, kapas, air pendingin.

Alat yang dibutuhkan antara lain gelas ukur, panci, kompor gas Rinnai RI-512 MS , timbangan digital (TANITA digital scale KD-321), baskom, food processor, scrapper, cookies spuit (NAGAKO Biscuits), sendok, thermocouple (CUSTOM CT-450WR), dan kulkas. Alat yang digunakan dalam analisis antara lain oven listrik, timbangan analit, kompor listrik, cawan petri, botol timbang, plat kaca, pemberat $35 \mathrm{~kg}$, labu Kjeldahl, erlenmeyer $125 \mathrm{ml}$, corong, gelas beker $250 \mathrm{ml}$ dan $500 \mathrm{ml}$, gelas ukur $100 \mathrm{ml}$, refluks, tanur, destilator, soxhlet, pipet ukur $1 \mathrm{ml}$, pipet ukur $10 \mathrm{ml}$, kertas saring, labu destilat, labu soxhlet, spatula.

\section{B. Metode}

\section{Pembuatan Sosis Ayam}

Pada penelitian ini dilakukan pembuatan sosis ayam dengan menggunakan formula berdasarkan formula terbaik dari studi sebelumnya yang dilakukan oleh Sofiana (2012) mengenai penambahan tepung protein kedelai sebagai pengikat pada sosis. Berikut merupakan tabel formulasi bahan sosis ayam yang merupakan hasil modifikasi dari formula terbaik Sofiana (2012) yang disajikan pada Tabel 1.

Tabel 1. Formulasi bahan sosis ayam

\begin{tabular}{|c|c|c|c|c|c|}
\hline \multirow[b]{2}{*}{ Bahan } & \multicolumn{4}{|c|}{$\begin{array}{c}\text { Bobot bahan (\%) pada } \\
\text { variasi: }\end{array}$} & \multirow[b]{2}{*}{$\begin{array}{c}\text { SPC } \\
20 \\
\% \\
\end{array}$} \\
\hline & $\begin{array}{c}\text { Kontro } \\
1\end{array}$ & $\begin{array}{l}\text { ISP } \\
10 \\
\% \\
\end{array}$ & $\begin{array}{c}\text { ISP } \\
20 \\
\% \\
\end{array}$ & $\begin{array}{c}\text { SPC } \\
10 \\
\% \\
\end{array}$ & \\
\hline $\begin{array}{l}\text { Tepun } \\
\text { g ISP }\end{array}$ & - & 10 & 20 & - & - \\
\hline $\begin{array}{l}\text { Tepun } \\
\text { g SPC } \\
\text { Tepun }\end{array}$ & - & - & - & 10 & 20 \\
\hline $\begin{array}{c}\mathrm{g} \\
\text { tapiok } \\
\mathrm{a}\end{array}$ & 15 & 15 & 15 & 15 & 15 \\
\hline $\begin{array}{l}\text { Daging } \\
\text { ayam }\end{array}$ & 100 & 90 & 80 & 90 & 80 \\
\hline $\begin{array}{l}\text { Minya } \\
\mathrm{k}\end{array}$ & 20 & 20 & 20 & 20 & 20 \\
\hline Garam & 3 & 3 & 3 & 3 & 3 \\
\hline Gula & 1 & 1 & 1 & 1 & 1 \\
\hline Lada & 0,2 & 0,2 & 0,2 & 0,2 & 0,2 \\
\hline $\begin{array}{l}\text { Bawan } \\
\text { g putih }\end{array}$ & 0,2 & 0,2 & 0,2 & 0,2 & 0,2 \\
\hline $\begin{array}{l}\text { Es / } \\
\text { Air es }\end{array}$ & 25 & 25 & 25 & 25 & 25 \\
\hline STPP & 0.5 & 0,5 & 0,5 & 0,5 & 0,5 \\
\hline
\end{tabular}

Keterangan:

Persentase bahan yang ditambahkan berdasarkan total bobot daging ayam 
Tahapan pembuatan sosis ayam pada penelitian ini didasarkan pada tahapan penelitian yang dilakukan oleh Anggraeni, dkk, 2014 dengan modifikasi sesuai hasil uji coba yang dilakukan oleh peneliti. Tahapan pembuatan sosis ayam adalah sebagai berikut:

1. Pencampuran

Pencampuran dilakukan dengan 2 tahapan, yaitu pencampuran daging ayam giling, air es, dan garam selama 2 menit. Selanjutnya pencampuran adonan pertama dengan minyak, STPP, ISP, STP, gula, tepung tapioca, dan bumbu selama 3 menit menggunakan food processor.

2. Pencetakan dalam selongsong

Dicetak dalam selongsong dengan panjang sosis ayam $10 \mathrm{~cm}$ secara hati-hati agar tidak terdapat gelembung udara.

3. Perebusan dan Pendinginan

Sosis dalam selongsong direbus pada suhu 85C selama 10 menit. Kemudian direndam pada air dingin suhu 15C selama 5 menit untuk mempertahankan bentuk sosis ayam.

4. Penyimpanan

Sosis yang sudah didinginkan disimpan dalam lemari es selama 24 jam untuk digunakan dalam analisis.

Berikut merupakan gaftar alir pembuatan sosis ayam:

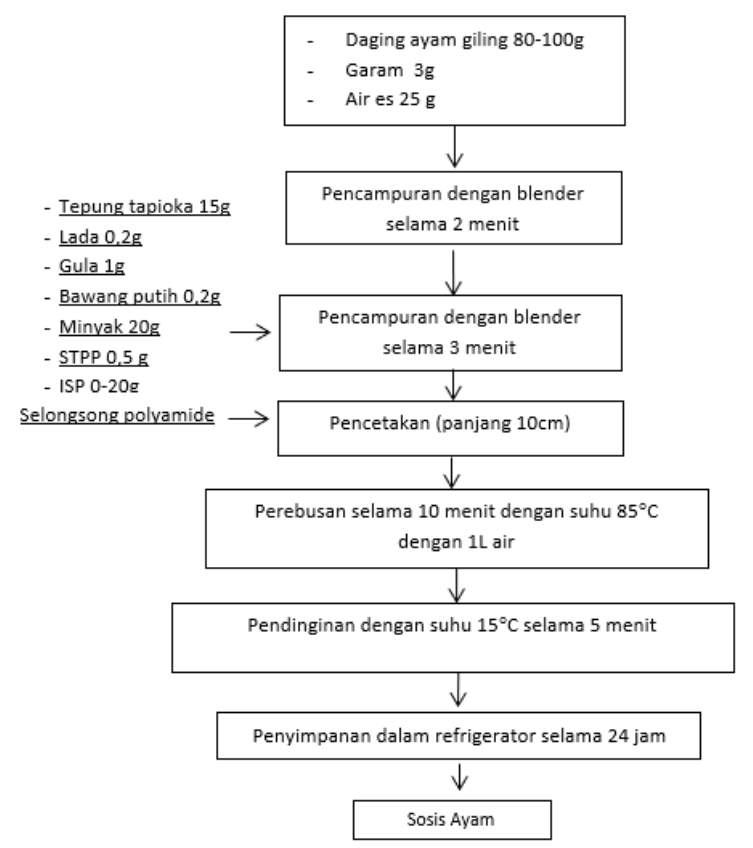

Gambar 1. Laju Alir Pembuatan Sosis Ayam

\section{Uji Proksimat}

Analisis Kadar Air Metode Termogravimetri (AOAC, 1984)

Sosis yang telah dihaluskan ditimbang sebanyak 1 gram dalam botol timbang yang telah diketahui beratnya. Sampel kemudian dikeringkan dalam oven pada suhu $100-105^{\circ} \mathrm{C}$ selama 3-5 jam, kemudian dinginkan dalam eksikator dan ditimbang. Panaskan lagi dalam oven selama 30 menit, dinginkan dalam eksikator dan ditimbang. Perlakuan serupa diulangi sampai tercapai berat konstan (selisih penimbangan berturut-turut kurang dari 0,2 mg).

Rumus perhitungan kadar air :

$$
\text { Kadar air }(\% w b)=\frac{(A+B)-C}{A} x 100 \%
$$

Keterangan: $A=$ berat sampel awal $\mathrm{B}=$ berat botol timbang awal $\mathrm{C}=$ berat botol + sampel setelah konstan

\section{Analisis Kadar Abu Metode Termogravimetri} (AOAC, 1984)

Sampel yang telah dibersihkan dan dikeringkan ditimbang 1 gram dalam kurs porselen yang kering dan telah diketahui beratnya. Sampel dalam kurs kemudian dipijarkan dalam muffle pada suhu $600^{\circ} \mathrm{C}$ sampai diperoleh abu berwarna keputih-putihan, kemudian tunggu sampai suhu turun menjadi $200^{\circ} \mathrm{C}$. Kurs dan abu kemudian dimasukkan ke dalam oven selama 3-5 jam dan didinginkan dalam eksikator kemudian ditimbang berat abu setelah dingin.

Rumus perhitungan kadar abu:

Kadar abu $(\% w b)=\frac{A-B}{C} x 100 \%$

Keterangan : A= berat kurs + abu

$\mathrm{B}=$ berat kurs

$\mathrm{C}=$ berat sampel

\section{Analisis Kadar Protein, Metode Mikro- Kjehldahl (AOAC, 1984)}

Sampel (sosis yang sudah ditepungkan) ditimbang sebanyak 0,1gram kemudian dimasukkan ke dalam labu Kjeldahl. Diambil 1 gram katalisator, 2,5mL asam sulfat pekat, kemudian dimasukkan ke dalam labu Kjeldahl yang telah berisi sampel. Sampel kemudian didestruksi selama 40 menit atau sampai sampel jernih, kemudian didinginkan. Setelah dingin, sampel dimasukkan ke dalam labu destilat dan cuci labu Kjeldahl beberapa kali dengan akuades, kemudian ditambahkan $8 \mathrm{~mL}$ natrium tiosulfat. Kemudian dilakukan distilasi, destilat ditampung sebanyak 70-100mL dalam Erlenmeyer yang berisi $5 \mathrm{~mL}$ asam borat, 3 tetes metil merah ditambah bromkresol. Larutan yang diperoleh 
kemudian dititrasi dengan $0,02 \mathrm{~N} \mathrm{HCl}$ sampai terjadi perubahan warna dari biru menjadi merah muda, kemudian volume $\mathrm{HCl}$ dicatat. Perlakuan yang sama dilakukan juga untuk blanko.

Rumus perhitungan :

$$
\% N=\frac{(m L H C l-m L \text { blank })}{m g \text { sampel } \times 1000} \times N \text { HCl } \times 14,008 \times f p
$$

$\%$ protein $(w b)=\% N x 6,25$

Keterangan: $\mathrm{fp}=$ faktor pengenceran

\section{Analisis Kadar Lemak Metode Soxhlet (AOAC, 1984)}

Ditimbang 1-2 gram bahan (sosis yang sudah ditepungkan) dimasukkan ke dalam timbel. Di atas timbel ditutup dengan kapas bebas lemak. Timbel kemudian dimasukkan ke dalam tabung ekstraksi soxhlet. Petroleum ether (PE) kemudian dimasukkan ke dalam tabung ekstraksi soxhlet dan ditampung dalam labu soxhlet yang telah diketahui berat konstannya. Air pendingin dialirkan melalui kondensor. Ekstraksi dibiarkan dengan sirkulasi PE selama 3-4 jam, kemudian residu yang mengandung minyak dalam labu soxhlet dimasukkan dalam oven $100^{\circ} \mathrm{C}$ untuk menguapkan PE dan sampai mencapai berat konstan. Berat minyak dalam labu soxhlet ditimbang dengan rumus sebagai berikut.

$$
\text { Kadar lemak }(\% w b)=\frac{A-B}{C} \times 100 \%
$$

Keterangan :

$\mathrm{A}=$ berat labu soxhlet +lemak atau minyak

$\mathrm{B}=$ berat labu soxhlet

$\mathrm{C}=$ berat sampel

\section{Uji sensoris}

Pengujian dilakukan terhadap lima sampel yang terdiri dari kontrol, ISP $10 \%$, ISP $20 \%$, SPC $10 \%$, dan SPC $20 \%$. Sampel disajikan secara acak kepada 30 panelis tidak terlatih yang merupakan mahasiswa FTP UGM. Dilakukan satu macam uji sensoris yaitu uji kesukaan.

Pengujian menggunakan metode scoring dengan 5 skala. Skala 1 menunjukan sangat tidak suka, skala 2 tidak suka, skala 3 netral, skala 4 suka, dan skala 5 sangat suka. Sosis yang akan diuji terlebih dahulu dimasak sebelum disajikan ke panelis. Pemasakan dilakukan dengan cara penggorengan. Sosis digoreng dengan ketebalan potongan $2 \mathrm{~cm}$ selama 30 detik pada wajan penggorengan dengan suhu $174^{\circ} \mathrm{C}$, lalu didinginkan di suhu ruang.

\section{Hasil Dan Pembahasan}

\section{A. Karakteristik kimia sosis ayam}

\section{Kadar Air}

Kadar air merupakan salah satu parameter yang cukup penting karena berkaitan dengan mutu. Kadar air dalam bahan pangan ikut menentukan tingkat penerimaan konsumen, kesegaran, dan daya tahan dari makanan tersebut (Triyono, 2010). Kadar air sosis ayam yang disubstitusi dengan ISP dan SPC dapat dilihat pada Tabel 2 .

Tabel 2. Kadar air sosis ayam yang disubstitusi

\begin{tabular}{|c|c|c|c|c|c|}
\hline \multirow[b]{2}{*}{ Parameter } & \multicolumn{5}{|c|}{ Perlakuan } \\
\hline & Kontrol & $\begin{array}{c}\text { ISP } \\
10 \%\end{array}$ & $\begin{array}{c}\text { ISP } \\
20 \%\end{array}$ & $\begin{array}{l}\text { SPC } \\
10 \%\end{array}$ & $\begin{array}{c}\text { SPC } \\
20 \%\end{array}$ \\
\hline $\begin{array}{l}\text { Kadar Air } \\
(\% \mathrm{~b} / \mathrm{b})\end{array}$ & $60,39^{a}$ & $57,00^{c}$ & 52,73 e & $57,59 \mathrm{~b}$ & $55,30^{d}$ \\
\hline \multicolumn{6}{|c|}{$\begin{array}{l}\text { Keterangan: Nilai rata-rata diperoleh dari } 3 \text { kali } \\
\text { ulangan perlakuan. Superskrip yang sama } \\
\text { menunjukkan tidak berbeda nyata (p>0,05) } \\
\text { menggunakan ANOVA dan uji lanjutan Duncan. } \\
\text { Superskrip yang berbeda menunjukkan berbeda } \\
\text { nyata (p< 0,05) menggunakan ANOVA dan uji } \\
\text { lanjutan Duncan. }\end{array}$} \\
\hline
\end{tabular}
dengan ISP dan SPC

Dari Tabel 2 dapat dilihat bahwa kadar air sosis ayam pada tiap perlakuan berkisar antara 52,7317-60,3933\% b/b. Batas maksimum kadar air sosis daging sesuai SNI adalah $67 \% \mathrm{~b} / \mathrm{b}$, dengan demikian kadar air sosis ayam pada tiap perlakuan memenuhi standar mutu SNI. Hasil uji statistik menunjukkan bahwa kadar air sosis ayam tiap perlakuan berbeda nyata $(\mathrm{p}<0,05)$ yang mana substitusi dengan ISP menurunkan kadar air lebih signifikan daripada SPC. Selain itu, konsentrasi ISP maupun SPC yang lebih tinggi juga menurunkan kadar air lebih signifikan.

Sosis ayam yang disubstitusi memiliki kadar air lebih rendah dikarenakan ISP maupun SPC yang berbentuk tepung memiliki kandungan air yang rendah sehingga substitusi menurunkan kadar air sosis ayam. Substitusi dengan ISP menurunkan kadar air lebih signifikan daripada SPC dikarenakan masih terdapatnya serat pada SPC yang mana serat tersebut memiliki kemampuan mengikat air yang baik (Y. S., Choi, et al., 2014).

\section{Kadar abu}

Kadar abu suatu bahan pangan menunjukkan banyaknya mineral yang terikat dalam suatu bahan (Yuniarifin et al., 2006). Kadar abu sosis ayam yang disubstitusi dengan ISP dan SPC dapat dilihat pada Tabel 3. 
Tabel 3. Kadar abu sosis ayam yang disubstitusi dengan ISP dan SPC

\begin{tabular}{lccccc}
\hline & \multicolumn{5}{c}{ Perlakuan } \\
\cline { 2 - 6 } Parameter & Kontrol & $\begin{array}{c}\text { ISP } \\
\text { ISP }\end{array}$ & $\mathbf{2 0 \%}$ & $\mathbf{1 0 \%}$ & $\mathbf{2 0 \%}$ \\
\hline $\begin{array}{l}\text { Kadar Abu } \\
(\% \mathrm{~b} / \mathrm{b})\end{array}$ & $2,16^{\mathrm{a}}$ & $2,39 \mathrm{a}$ & $2,53^{\mathrm{a}}$ & $2,25^{\mathrm{a}}$ & $2,55^{\mathrm{a}}$ \\
\hline
\end{tabular}

Keterangan: Nilai rata-rata diperoleh dari 3 kali ulangan perlakuan. Superskrip yang sama menunjukkan tidak berbeda nyata $(p>0,05)$ menggunakan ANOVA dan uji lanjutan Duncan. Superskrip yang berbeda menunjukkan berbeda nyata $(\mathrm{p}<0,05)$ menggunakan ANOVA dan uji lanjutan Duncan. Hal tersebut berlaku pada kolom yang sama.

Dari tabel 3, dapat dilihat bahwa kadar abu sosis ayam pada tiap perlakuan berkisar antara 2,1656-2,5500 \% b/b. Batas maksimum kadar abu sosis daging sesuai SNI adalah $3 \% \mathrm{~b} / \mathrm{b}$, dengan demikian kadar abu sosis ayam pada tiap perlakuan tidak melebihi syarat SNI. Oleh karena itu, disimpulkan bahwa sosis ayam pada tiap perlakuan memenuhi standar mutu SNI berdasarkan kadar abu.

Hasil uji statistik menunjukkan bahwa kadar abu sosis ayam tiap perlakuan tidak berbeda nyata $(p>0,05)$. Hal tersebut sesuai dengan yang dilaporkan oleh Z. L., Kang et al (2016) bahwa kadar abu pada frankfurter dengan ISP tidak berbeda signifikan dengan kontrol dan A. N. Rinaldoni et al. (2014) yang menyatakan bahwa kadar abu pada keju yang ditambahkan SPC mengalami sedikit penurunan tetapi tidak signifikan $(p>0,05)$.

\section{Kadar lemak}

Lemak merupakan golongan senyawa organik kedua yang menjadi sumber makanan, merupakan kira-kira $40 \%$ dari makanan yang dimakan sehari-hari (Iskandar, 2004). Hasil analisis kadar lemak dapat dilihat pada Tabel 4.

Tabel 4. Kadar lemak sosis ayam yang disubstitusi dengan ISP dan SPC

\begin{tabular}{lccccc}
\hline \multirow{2}{*}{ Parameter } & \multicolumn{5}{c}{ Perlakuan } \\
\cline { 2 - 6 } & \multirow{2}{*}{ Kontrol } & ISP & ISP & SPC & SPC \\
& & $\mathbf{1 0 \%}$ & $\mathbf{2 0 \%}$ & $\mathbf{1 0 \%}$ & $\mathbf{2 0 \%}$ \\
\hline Kadar & & & & & \\
Lemak & $12,21^{\mathrm{a}}$ & $9,91^{\mathrm{b}}$ & $8,33^{\mathrm{c}}$ & $9,88^{\mathrm{b}}$ & $9,56^{\mathrm{b}}$ \\
$(\% \mathrm{~b} / \mathrm{b})$ & & & & & \\
\hline
\end{tabular}

Keterangan: Nilai rata-rata diperoleh dari 3 kali ulangan perlakuan. Superskrip yang sama menunjukkan tidak berbeda nyata $(p>0,05)$ menggunakan ANOVA dan uji lanjutan Duncan. Superskrip yang berbeda menunjukkan berbeda nyata $(p<0,05)$ menggunakan ANOVA dan uji lanjutan Duncan. Hal tersebut berlaku pada kolom yang sama.

Dari tabel 4 dapat dilihat bahwa kadar lemak sosis ayam pada tiap perlakuan berkisar antara 8,3363-12,2134 \% b/b. Batas maksimum kadar lemak sosis daging sesuai SNI adalah $20 \%$ $\mathrm{b} / \mathrm{b}$, dengan demikian kadar lemak sosis ayam pada tiap perlakuan tidak melebihi syarat SNI. Oleh karena itu, disimpulkan bahwa sosis ayam pada tiap perlakuan memenuhi standar mutu SNI berdasarkan kadar lemak.

Hasil uji statistik menunjukkan bahwa kadar lemak sosis ayam tiap perlakuan berbeda nyata $(p<0,05)$ yang mana substitusi menurunkan kadar lemak sosis. Substitusi dengan ISP dan SPC menurunkan kadar lemak secara signifikan, tetapi penambahan konsentrasi pada SPC tidak menurunkan kadar lemak secara siginifikan. Hal tersebut sesuai dengan yang dilaporkan oleh Kang et al. (2016) bahwa kadar lemak pada frankfurter dengan ISP lebih rendah dibandingkan dengan kontrol.

\section{4.}

\section{Kadar protein}

Protein merupakan zat makanan yang amat penting bagi tubuh karena disamping berfungsi sebagai bahan bakar dalam tubuh juga berfungsi sebagai zat pembangun dan pengatur. Protein merupakan sumber sejumlah asam amino yang mengandung unsur $\mathrm{C}, \mathrm{H}, \mathrm{O}$ dan $\mathrm{N}$ yang tidak dimiliki oleh lemak atau karbohidrat (Rodwell, et al, 2000 dalam Husni, et al.,2008). Hasil analisis kadar protein dapat dilihat pada Tabel 5.

Tabel 5. Kadar protein sosis ayam yang disubstitusi dengan ISP dan SPC

\begin{tabular}{lccccc}
\hline & \multicolumn{5}{c}{ Perlakuan } \\
\cline { 2 - 6 } Parameter & Kontr & ISP & ISP & SPC & SPC \\
& ol & $\mathbf{1 0 \%}$ & $\mathbf{2 0 \%}$ & $\mathbf{1 0 \%}$ & $\mathbf{2 0 \%}$ \\
\hline Kadar & & 14,46 & 17,17 & 12,06 & \\
Protein & 11,17 a & b & c & a & $14,99 b$ \\
$(\%$ b/b) & & & & & \\
\hline
\end{tabular}

Keterangan: Nilai rata-rata diperoleh dari 3 kali ulangan perlakuan. Superskrip yang sama menunjukkan tidak berbeda nyata $(p>0,05)$ menggunakan ANOVA dan uji lanjutan Duncan. Superskrip yang berbeda menunjukkan berbeda nyata $(\mathrm{p}<0,05)$ menggunakan ANOVA dan uji lanjutan Duncan. Hal tersebut berlaku pada kolom yang sama.

Dari tabel 5 dapat dilihat bahwa kadar protein sosis ayam pada tiap perlakuan berkisar antara 11,1768-17,1720 \% b/b. Batas minimum kadar protein sosis daging sesuai SNI adalah $8 \%$ $\mathrm{b} / \mathrm{b}$, dengan demikian kadar protein sosis ayam pada tiap perlakuan tidak kurang dari syarat SNI. Oleh karena itu, disimpulkan bahwa sosis ayam 
pada tiap perlakuan memenuhi standar mutu SNI berdasarkan kadar protein.

Hasil uji statistik menunjukkan bahwa kadar protein sosis ayam tiap perlakuan berbeda nyata $(\mathrm{p}<0,05)$ yang mana substitusi meningkatkan kadar protein sosis. Substitusi dengan ISP meningkatkan kadar protein secara signifikan, tetapi SPC tidak. Kadar protein sosis yang disubstitusi dengan SPC meningkat secara signifikan ketika konsentrasinya sebesar $20 \%$.

Penelitian sebelumnya melaporkan bahwa peningkatan konsentrasi ISP akan meningkatkan kadar protein secara signifikan (Kang et al., 2016). Peningkatan konsentrasi SPC juga meningkatkan kadar protein secara signifikan $(\mathrm{p}<0,05)$ (Rinaldoni et al., 2014).

\section{B. UJI KESUKAAN SOSIS AYAM}

Hasil analisis uji kesukaan sosis ayam dapat dilihat pada gambar 1. Hasil uji ditunjukkan dengan angka yang mana angka 1 berarti sangat tidak suka, 2 berarti tidak suka, 3 berarti tidak suka maupun suka, 4 berarti suka, dan 5 berarti sangat suka.

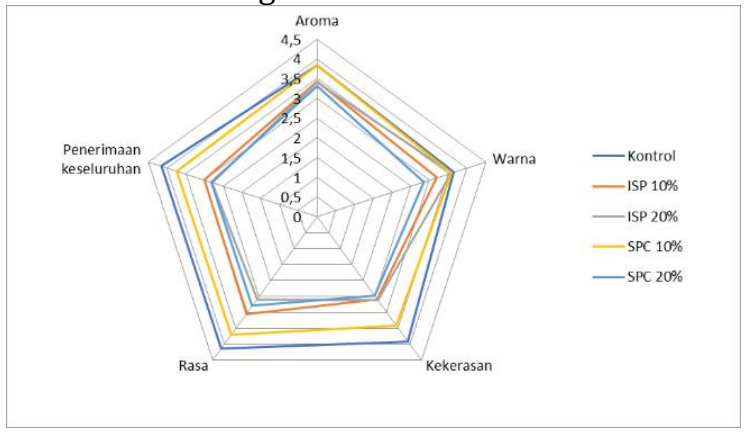

Gambar 1. Hasil analisis uji kesukaan sosis ayam

\section{Warna}

Warna produk dipengaruhi oleh berbagai faktor seperti warna daging ayam, penambahan subtitusi ISP maupun SPC, pengaruh lingkungan, pengaruh penambahan bahan tambahan makanan seperti bumbu, dan pengaruh perlakuan pengolahan lainnya. Pemasakan yang dilakukan dalam penelitian ini adalah penggorengan. Proses pemasakan ini dapat menimbulkan perubahan warna menjadi kecoklatan. Hasil penilaian panelis terhadap parameter warna lebih menyukai sosis dengan substitusi ISP 20\% dan SPC 10\% yang nilainya tidak berbeda secara siginifikan dengan kontrol. Hasil penilaian panelis terhadap parameter warna dapat dilihat pada Tabel 6.
Tabel 6. Hasil penilaian panelis terhadap parameter warna

\begin{tabular}{lccccc}
\hline \multirow{2}{*}{ Parameter } & \multicolumn{5}{c}{ Perlakuan } \\
\cline { 2 - 6 } & Kontro & ISP & ISP & SPC & SPC \\
& $\mathbf{1}$ & $\mathbf{1 0 \%}$ & $\mathbf{2 0 \%}$ & $\mathbf{1 0 \%}$ & $\mathbf{2 0 \%}$ \\
\hline \multirow{2}{*}{ Warna } & $3,63^{\mathrm{a}}$ & $3,20^{\mathrm{a}}$ & $3,58^{\mathrm{a}}$ & $3,58^{\mathrm{a}}$ & $2,84^{\mathrm{b}}$ \\
& & $\mathrm{b}$ & & & \\
\hline
\end{tabular}

Keterangan: Nilai rata-rata diperoleh dari 2 kali ulangan perlakuan. Superskrip yang sama menunjukkan tidak berbeda nyata $(p>0,05)$ menggunakan ANOVA dan uji lanjutan Duncan. Superskrip yang berbeda menunjukkan berbeda nyata $(\mathrm{p}<0,05)$ menggunakan ANOVA dan uji lanjutan Duncan.

\section{Kekerasan}

Penambahan subtitusi isolat protein maupun bahan tambahan makanan seperti sodium tripolyphosphate juga mempengaruhi sifat-sifat sosis. Penambahan SPC dan ISP dapat mempengaruhi tekstur sosis. Apabila konsentrasi SPC dan ISP ditingkatkan lagi maka akan mempengaruhi daya mengikat air sehingga berpengaruh pada tekstur sosis. Suhu pemasakan juga mempengaruhi tekstur produk. Kesegaran daging akan memperbaiki tekstur produk menjadi lebih lembut. Hasil penilaian panelis terhadap parameter kekerasan paling menyukai sosis dengan substitusi SPC 10\% yang nilainya tidak berbeda signifikan dengan kontrol. Hasil penilaian panelis terhadap parameter kekerasan dapat dilihat pada Tabel 7.

Tabel 7. Hasil penilaian panelis terhadap parameter kekerasan

\begin{tabular}{lccccc}
\hline \multirow{2}{*}{ Parameter } & \multicolumn{5}{c}{ Perlakuan } \\
\cline { 2 - 6 } & Kontr & ISP & ISP & SPC & SPC \\
& ol & $\mathbf{1 0 \%}$ & $\mathbf{2 0 \%}$ & $\mathbf{1 0 \%}$ & $\mathbf{2 0 \%}$ \\
\hline \multirow{2}{*}{ Kekerasan } & $3,91^{\mathrm{a}}$ & $2,60^{\mathrm{b}}$ & 2,62 & $3,41^{\mathrm{ab}}$ & 2,48 \\
& & & $\mathrm{~b}$ & & $\mathrm{~b}$ \\
\hline
\end{tabular}

Keterangan: Nilai rata-rata diperoleh dari 2 kali ulangan perlakuan. Superskrip yang sama menunjukkan tidak berbeda nyata $(p>0,05)$ menggunakan ANOVA dan uji lanjutan Duncan. Superskrip yang berbeda menunjukkan berbeda nyata $(\mathrm{p}<0,05)$ menggunakan ANOVA dan uji lanjutan Duncan.

\section{Rasa}

Hasil penilaian panelis terhadap parameter rasa lebih menyukai sosis dengan substitusi SPC 10\% dan ISP 10\% yang nilainya tidak berbeda signifikan dengan kontrol. Hasil penilaian panelis terhadap parameter rasa dapat dilihat pada Tabel 8. 
Tabel 8. Hasil penilaian panelis terhadap parameter rasa

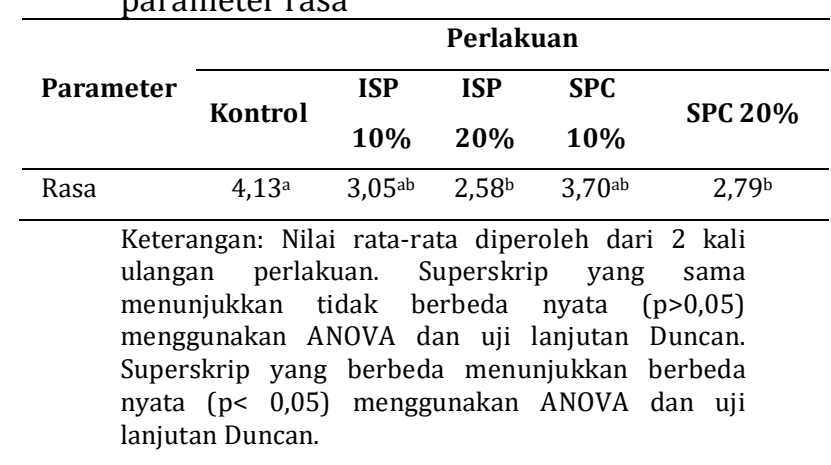

\section{Aroma}

Hasil penilaian panelis terhadap parameter aroma menunjukkan bahwa seluruh sosis dengan substitusi disukai karena nilainya tidak berbeda signifikan dengan kontrol. Hasil penilaian panelis terhadap parameter aroma dapat dilihat pada Tabel 9.

Tabel 9. Hasil penilaian panelis terhadap parameter aroma

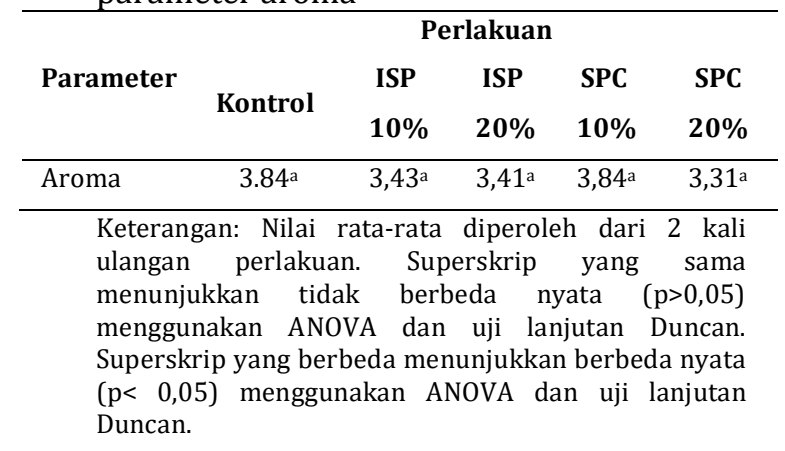

\section{Penerimaan keseluruhan}

Hasil penilaian panelis secara keseluruhan menunjukkan bahwa sosis dengan substitusi SPC $10 \%$ paling disukai karena nilainya tidak berbeda signifikan dengan kontrol. Hal tersebut sesuai karena seluruh parameter juga menunjukkan bahwa nilai sosis dengan substitusi SPC $10 \%$ tidak berbeda siginifikan dengan kontrol. Hasil penilaian panelis secara keseluruhan dapat dilihat pada Tabel 10.

Tabel 10. Hasil penilaian panelis terhadap seluruh parameter

\begin{tabular}{|c|c|c|c|c|c|}
\hline \multirow[b]{2}{*}{ Parameter } & \multicolumn{5}{|c|}{ Perlakuan } \\
\hline & $\begin{array}{c}\text { Kontr } \\
\text { ol }\end{array}$ & $\begin{array}{c}\text { ISP } \\
10 \%\end{array}$ & $\begin{array}{c}\text { ISP } \\
20 \%\end{array}$ & $\begin{array}{l}\text { SPC } \\
10 \%\end{array}$ & $\begin{array}{c}\text { SPC } \\
20 \%\end{array}$ \\
\hline Keseluruhan & $4.15^{\mathrm{a}}$ & $3,00^{\mathrm{b}}$ & $2,79^{b}$ & $3,741^{b}$ & $2,81^{b}$ \\
\hline \multicolumn{6}{|c|}{$\begin{array}{l}\text { Keterangan: Nilai rata-rata diperoleh dari } 2 \text { kali } \\
\text { ulangan perlakuan. Superskrip yang sama } \\
\text { menunjukkan tidak berbeda nyata (p>0,05) } \\
\text { menggunakan ANOVA dan uji lanjutan Duncan. } \\
\text { Superskrip yang berbeda menunjukkan berbeda nyata } \\
\text { (p< 0,05) menggunakan ANOVA dan uji lanjutan } \\
\text { Duncan. }\end{array}$} \\
\hline
\end{tabular}

\section{Kesimpulan}

1. Substitusi dengan ISP dan SPC meningkatkan kadar protein dan juga menurunkan kadar air, dan kadar lemak tetapi tidak berpengaruh siginifikan terhadap kadar abu.

2. Sosis ayam yang disubstitusi memenuhi syarat mutu SNI berdasarkan kadar air, kadar abu, kadar lemak, dan kadar protein.

3. Sosis ayam yang dapat diterima oleh masyarakat hanya sosis yang disubstitusi dengan SPC 10\% karena tingkat kesukaannya paling mendekati kontrol.

\section{Daftar Pustaka}

Anggraeni, D.A., Widjanarko, S.B., dan Ningtyas, D.W., 2014. Proporsi Tepung Porang (Amorphophallus muelleri Blume) : Tepung Maizena terhadap Karakteristik Sosis Ayam. Jurnal Pangan dan Agroindustri 2, 3: 214-223.

AOAC, 1984. Official Methods of Analysis. 11th edition. Association of Official Analitical Chemists, Inc. Washington D.C.

Choi, Y.S., Kim, H.W., Hwang, K.E., Song, D.H., Choi, J.H., Lee, M.A., Chung, H.J., Kim, C.J., 2014. Physicochemical properties and sensory characteristics of reduced-fat frankfurters with pork back fat replaced by dietary fiber extracted from makgeolli lees. Meat Science 96: 892-900.

Direktorat Jenderal Peternakan dan Kesehatan Hewan, 2016. Data Produksi Sub Sektor Peternakan.

www.pertanian.go.id/ap_pages/mod/datana k. Diakses tanggal 19 Mei 2017.

Hartono, 2015. Telah Disepakati Alokasi Impor Daging Sapi untuk Industri tahun 2015. Siaran Pers. www.kemenperin.go.id. Diakses tanggal 19 Mei 2017.

Husni, Elidahanum., Samah, Asmaedy., Rec, Anriati., 2008. Analisa Zat Pengawet dan Protein dalam Makanan Siap Saji Sosis. Jurnal Sains dan Teknologi Farmasi. Vol. 13. No. 1. p. 1-6.

Iskandar, Y., 2004. Penentuan Kadar Asam Linoleat pada Tempe secara Kromatografi Gas. Abstrak. Universitas Padjajaran. Bandung.

Kang, Zhuan Li., Chen, Fu-sheng., Ma, Han-ju., 2016. Effect of Pre-emulsified Soy Oil with Soy Protein Isolate in Frankfurters: A Physicalchemical and Raman Spectroscopy Study. LWT - Food Science and Technology 74: 465471.

Rinaldoni, Ana N., Palatnik, Diana R., Zaritzky, Noemi., Campderros, Mercedes E., 2014. Soft cheese-like product development enriched with soy protein concentrates. LWT - Food Science and Technology 55: 139-147. 
Sofiana, A., 2012. Penambahan Tepung Protein Kedelai sebagai Pengikat pada Sosis Sapi. Jurnal Ilmiah Ilmu-IImu Peternakan. Vol. XV. No. 1. p. 1-7.

Triyono, A., 2010. Mempelajari Pengaruh Penambahan Beberapa Asam pada Proses Isolasi Protein terhadap Tepung Protein Isolat Kacang Hijau (Phaseoulus radiatus L.). Seminar Rekayasa Kimia dan Proses. Semarang.

Winarno, F. G., 2002. Kimia Pangan dan Gizi. PT. Gramedia. Jakarta.

Yuniarifin, H., Bintoro, V.P., Suwarastuti, A., 2006. Pengaruh Berbagai Konsentrasi Asam Fosfat pada Proses Perendaman Tulang Sapi terhadap Rendemen, Kadar Abu, dan Viskositas Gelatin. J. Indon. Trop. Anim. Agric. 31 [1]: 55-61. 